\title{
MARKING GHANGE IN METHODS OF TRANSMISSION
}

Discussing industrial conditions President Roosevelt in an address at Cincinnati, September 20, 1902; stated the re: markable fact that here a century ago news was transmitted and merchandise carried exactly as in the days of the Roman Empire. We had on our rivers the flatboat and on the ocean the sailing-ship, we had the pack-train and we had the wagon: "Every one of the four was known when Babylon fell." The change in the last one hundred years has been greater by far than the changes in all the preceding three thousand years. Applied to lowa, our life was well established before a different method from these four materially affected us. The Black Hawk purchase was populated, its surface made habitable, its commerce established, its township, county and territorial government fixed under the Babylonish era of transmission and transportation. The State of Iowa, then, is coincident with a new and most wonderful era of methods for interchange of intellectual and physical properties. In this fact is the basis of much controversy in every field of American life. Litigation, legislation, and commerce in Iowa are most concerned now with conditions that were merely dawning when our present constitution was adopted in 1857 .

Conceiving that the last of the old tavern days and the first of the Pullman car epoch are but just out of memory of the present generation, the Historical Department joined a scheme of the Iowa Railway Club in promoting at Des Moines in May last a reunion of "Old time railway men." The Department's share in the enterprise was merely to invite the accumulation of objects and materials touching the handling of information and traffic in the active period of the lives of these men. Such objects were assembled in the Department museum and contributed much to the interest of the occasion. Most of the exhibit passed permanently into the collections of the Department.

The plan was of value both for the objects acquired and for disclosing those apparently not now obtaindble. For instance, the telegraph instrument in universal use by the first. 
Iowa trunk-lines and telegraph companies, which wrote out its messages on tapes in the Morse dot and dash alphabet seems to have completely vanished, and no old timer was able to provide one for the exhibit. But there was assembled a most interesting and instructive documentary collection illustrative of the operating methods of the first railroad days in Iowa. General rules, train orders, schedules, freight books, hat checks, photographs and personal letters disclosed the establishment and development of method not before known in the handling of men out of military life. There were assembled also the predecessors of the present day time-table in some numbers. These are the pocket "traveler's guides" common in the stage coach and steamboat days. They are folding maps by Colton, by Mitchell and others, usually con. taining tables of distances, charges, census items, land laws and similar data. Many valuable cuts and illustrations designed to fire the public desire to travel, such as Centennial Exposition literature, Rocky Mountain travel enticements and western homestead and other land inducements. The acquisition was made of one of the old "prairie schooners" whose handwrought timbers and iron members bore its great burdens over the National Road from Wheeling west in 1820 and until routed out by the railroads. Then it came to Iowa and other portions of the west until deposed from business on the Sante Fe Trail by its everlasting competitor. It left its legitimate character in Oklahoma to return to Iowa as a curiosity in the parade of a medicine show and when by that enterprise abandoned was brought in from the weather to remain in the collections: It will have part in the Iowa State Fair exhibitions as an object of instruction to the mechanic and industrial student of Iowa, having within the memory of Iowa pioneers become quite as unknown to the youth of the State as the Spanish galleon or Ohio keel-boat. The Department recognizes, and expects to provide as best it may, the materials from which may be studied that portion of our history which has for a half century been and will for the future be, more largely than ever before, made by men not alone in the lines of statecraft or in war; that part. wherein 
a people's course is being affected and perhaps directed by new conditions, not to say a new force, comparable with any of the old.

\section{IOWA SENATORIAL SUCCESSION.}

When the federal constitution was adopted, Article I, Section 3, clause 2, provided that the United States Senators should be divided into three classes, the first to serve for a period of two years; the second, for a period of four years and the third for a period of six years, thus providing for a continuity of that body. When Iowa was admitted into the Union her two United States Senators, George W. Jones of Dubuque and Augustus C. Dodge of Burlington fell, respectively, into classes two and three. They began their service in the Senate on the same day, December 7, 1848. Jones was 44 years of age and Dodge was 32 . Succeeding Jones, James W. Grimes of Burington was installed, March 4, 1859, at 42, being re-elected and re-installed March 4, 1865, resigning his office December 6, 1869. Mr. Grimes was succeeded by James B. Howell, of Keokuk, at 53 years of age, who was installed January 18, 1870, and retired at the end of Mr. Grimes' second term, March 3, 1871. Mr. Howell was succeeded by George G. Wright, of Des Moines, at 51 years of age, on March 4, 1871, who served one term, retiring March 3, 1877. Mr. Wright was succeeded by Samuel J. Kirkwood, of Iowa City, at 63, March 4, 1877, who resigned March 7, 1881, James W. McDill of Creston, at 46, succeeding him March 8, 1881, being appointed by Governor Gear, and serving out the Kirkwood term, retiring March 3, 1883. James F. Wilson of Fairfield, at 54, was installed March 4, 1883, and served continuously until March 3, 1895, being succeeded by John $\mathrm{H}$. Gear of Burlington, at 69, March 4, 1895. Mr. Gear died on July 14, 1900, and Jonathan P. Dolliver of Fort Dodge, after appointment by Governor Shaw, was installed August 22, 1900, at 42 years of age, serving to the end of Gear's term March 3, 1901, and, by election, until the present time, the term ending March 3, 1913. 
Copyright of Annals of Iowa is the property of State of Iowa, by \& through the State Historical Society of Iowa and its content may not be copied or emailed to multiple sites or posted to a listserv without the copyright holder's express written permission. However, users may print, download, or email articles for individual use. 